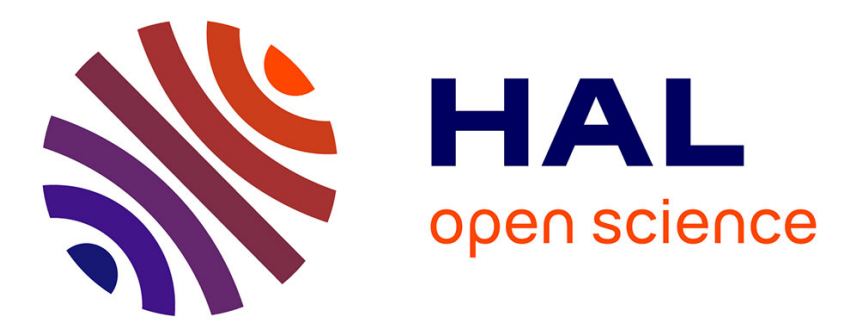

\title{
Evidence for brittle deformation events at eclogite-facies P-T conditions (example of the Mt. Emilius klippe, Western Alps)
}

Solenn Hertgen, Philippe Yamato, Luiz F.G. Morales, Samuel Angiboust

\section{To cite this version:}

Solenn Hertgen, Philippe Yamato, Luiz F.G. Morales, Samuel Angiboust. Evidence for brittle deformation events at eclogite-facies P-T conditions (example of the Mt. Emilius klippe, Western Alps). Tectonophysics, 2017, 706-707, pp.1-13. 10.1016/j.tecto.2017.03.028 . insu-01502746

\section{HAL Id: insu-01502746 \\ https://hal-insu.archives-ouvertes.fr/insu-01502746}

Submitted on 6 Apr 2017

HAL is a multi-disciplinary open access archive for the deposit and dissemination of scientific research documents, whether they are published or not. The documents may come from teaching and research institutions in France or abroad, or from public or private research centers.
L'archive ouverte pluridisciplinaire HAL, est destinée au dépôt et à la diffusion de documents scientifiques de niveau recherche, publiés ou non, émanant des établissements d'enseignement et de recherche français ou étrangers, des laboratoires publics ou privés. 


\section{Accepted Manuscript}

TEGTONOPHYSICS

Evidence for brittle deformation events at eclogite-facies P-T conditions (example of the Mt. Emilius klippe, Western Alps)

Solenn Hertgen, Philippe Yamato, Luiz F.G. Morales, Samuel Angiboust

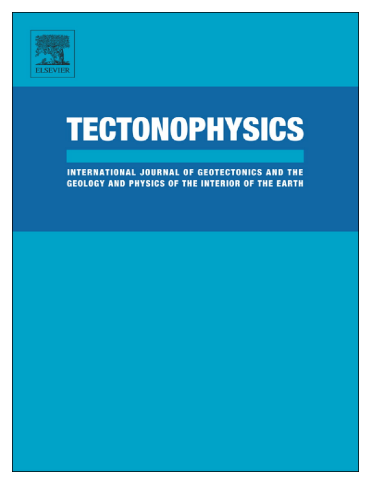

PII:

S0040-1951(17)30127-0

DOI:

doi: $10.1016 /$ j.tecto.2017.03.028

Reference:

TECTO 127445

To appear in:

Tectonophysics

Received date:

30 August 2016

Revised date:

26 March 2017

Accepted date:

29 March 2017

Please cite this article as: Solenn Hertgen, Philippe Yamato, Luiz F.G. Morales, Samuel Angiboust, Evidence for brittle deformation events at eclogite-facies P-T conditions (example of the Mt. Emilius klippe, Western Alps). The address for the corresponding author was captured as affiliation for all authors. Please check if appropriate. Tecto(2017), doi: $10.1016 /$ j.tecto.2017.03.028

This is a PDF file of an unedited manuscript that has been accepted for publication. As a service to our customers we are providing this early version of the manuscript. The manuscript will undergo copyediting, typesetting, and review of the resulting proof before it is published in its final form. Please note that during the production process errors may be discovered which could affect the content, and all legal disclaimers that apply to the journal pertain. 


\section{Evidence for brittle deformation events at eclogite-facies $P-T$ conditions (example of the Mt. Emilius klippe, Western Alps).}

Solenn Hertgen ${ }^{a, b, *}$, Philippe Yamato ${ }^{a, b}$, Luiz F.G. Morales ${ }^{c}$ and Samuel Angiboust $^{d, e}$

${ }^{a}$ Géosciences Rennes, Université de Rennes 1, Rennes F-35042, France

${ }^{\mathrm{b}}$ CNRS, UMR 6118, Rennes F-35042, France

${ }^{c}$ Eidgenössische Technische Hochschule (ETH), Auguste-Piccard-Hof 1, CH-8093 Zürich,

Switzerland

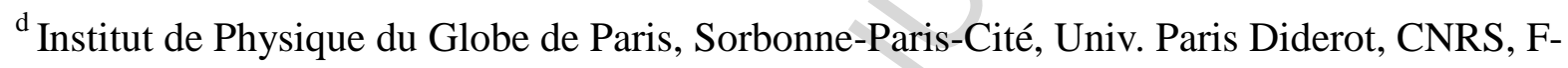
75005 Paris, France

${ }^{\mathrm{e}}$ German Research Center for Geosciences (GFZ), Helmholtz Zentrum, Potsdam D-14473,

Germany

*Corresponding author: solenn.hertgen@univ-rennes1.fr

Geosciences Rennes, UMR CNRS 6118

B. 15,1 st floor, Office 127

Université de Rennes1, Campus de Beaulieu

CS 74205 F-35 042 Rennes France

Submission to: Tectonophysics 


\section{Abstract}

Eclogitic rocks are crucial for the understanding of tectonic processes as they provide key constraints on both the $P-T-t$ evolutions and the deformation modes sustained by rocks in subduction zones. Here we focus on eclogitised and deformed mafic bodies that are exposed within granulites from the continental basement slice of the Mt. Emilius klippe (Western Alps, Italy). These eclogites exhibit highly deformed garnetite and clinopyroxenite layers. In some places, these deformed rocks (up to mylonitic grade) can be found as clasts within meter-thick brecciated fault rocks that formed close to the lawsonite-eclogite facies peak $P-T$ conditions. Garnet-rich layers are dominated by brittle features, whereas deformation within clinopyroxene-rich layers is accommodated by both creep and fracturing. We present a petrostructural study of these eclogites, that allows to track the brittle deformation history associated with chemical evolution. Based on these data, we propose a new tectonometamorphic model for these rocks, related to the alpine eclogitic stage. This model is consistent with the coexistence of both ductile and brittle features that developed at similar $P$ $T$ conditions (i.e., at $P \sim 2.15-2.40 \mathrm{GPa}$ and $T \sim 500-550{ }^{\circ} \mathrm{C}$ ), and closely associated with fluid circulations. Our study demonstrates that crustal material, buried along the subduction interface at $H P$ - $L T$ conditions, can record several successive brittle events in places where deformation is classically envisioned as ductile. We suggest, based on our observations, that strain-rate increase along plate interface shear zones may trigger fracturing and fluid infiltration which in turn enables brittle-ductile instabilities along these deformation networks.

keywords: brittle-ductile deformation, eclogite breccias, fluid-rock interaction, subduction interface 


\section{Introduction}

The rocks constituting Earth's crust are traditionally thought to deform in a brittle manner at shallow depths and by ductile flow at deeper levels (e.g., Brace and Kohlstedt, 1980; Ranalli and Murphy, 1987). The transition between the brittle crust, affected by discontinuous deformation (i.e., fracture-dominated), and the ductile crust, affected by continuous deformation (i.e., flow-dominated), known as the brittle-ductile transition, is characterised by networks of shear zones where both modes of deformation coexist (e.g., Handy and Brun, 2004; Hobbs et al., 1986; Passchier, 1984).

However, field observations, geophysical studies, and laboratory experiments indicate that brittle and ductile deformation mechanisms can actually affect rocks at all crustal levels (e.g., Abers et al., 2006; Angiboust et al., 2011, 2012; Austrheim and Andersen, 2004; Mancktelow, 2009; Pennacchioni and Cesare, 1997; Simpson, 1985). For instance, the formation of brittle features of various length scale, such as breccias, pseudotachylytes and fractured garnets, has been documented for pressure $(P)$ and temperature $(T)$ conditions up to eclogite-facies conditions, in both hydrated oceanic crust (e.g., Austrheim and Andersen, 2004; Angiboust et al., 2012; John and Schenk, 2003) and dry continental crust (e.g., Austhreim et al., 1996). The origin of these brittle structures can be related to seismic faulting, intermediate-depth earthquakes, and/or fluid percolation (e.g., Angiboust et al., 2012; Austrheim and Boundy, 1994; Austrheim et al., 1997; Engvik et al., 2001; Hacker et al., 2003; John and Schenk, 2006; Lund and Austrheim, 2003; Rietbrock and Waldhauser, 2004). In many cases, these brittle structures are precursors on which ductile shear zones nucleated (e.g., Brodie and Rutter, 1987; Lund and Austrheim, 2003; Pennacchioni, 2005; Pennacchioni and Mancktelow, 2007; Segall and Simpson, 1986). 
In addition, field evidence, microstructural observations, and chemical data show that both brittle and ductile deformation modes can occur simultaneously up to eclogite-facies conditions (e.g., Angiboust et al., 2012; Lund and Austrheim, 2003). However, there is a need to explain the coexistence (both in space and time) of these two deformation modes at identical $P$ - $T$ conditions. In order to address this issue, we present the results of a petrostructural study performed on eclogites exposed within the continental-derived tectonic slice of the Mt. Emilius klippe (Western Alps, Italy). These rocks have been highly deformed in a ductile manner, but also exhibit brecciated features (Pennacchioni, 1996). Therefore, they constitute an excellent opportunity for improving our understanding of deformation mechanisms affecting rocks buried in subduction zones.

Based on a multi-scale (i.e., from outcrop- to grain-scale) and a multi-method analytical approach (i.e., optical and electron microscopy, electron microprobe and electron backscatter diffraction analyses), we propose a new tectono-metamorphic model for the formation of the eclogites located within a major shear zone (Arbolle shear zone) at the base of the Mt. Emilius klippe, which involves concomitant brittle and ductile deformation at the metamorphic peak, in the eclogite-facies $P-T$ conditions, and associated with multiple fluid circulation events. We finally discuss possible implications for deformation mechanisms, fluid circulations and fluid/rock interactions taking place in subduction zones under high pressure $(H P)$ conditions.

\section{Geological setting of the Mt. Emilius klippe}

\subsection{Origin and affinity}

The Mt. Emilius klippe is exposed in the southern Aosta valley (Piemonte units, Italy) 
and overlies the Piemonte meta-ophiolites (Fig. 1a). This klippe corresponds to a continental basement unit, belonging to the austro-alpine nappe-stack (Ballèvre et al., 1986) and connected to the Jurassic margin of the Adriatic plate. The continental basement slices (e.g., Mt. Emilius klippe, Glacier-Raffray unit, Etirol-Levaz slice, Theodul Glacier unit) constitute the "inferior austro-alpine units" (Ballèvre et al., 1986; Weber and Bucher, 2015) or "eclogitic lower austro-alpine outliers" (Dal Piaz et al., 1999). They crop out between the lower grade Combin unit, and the higher grade Zermatt-Saas unit (Dal Piaz et al., 2001). These continental slices contain both mafic and felsic intrusions (e.g., Beltrando et al., 2010; Dal Piaz and Nervo, 1971), and record a multi-stage metamorphic history, pervasive deformation, and numerous reactived pre-alpine contacts during alpine subduction and exhumation (Compagnoni et al., 1977; Beltrando et al., 2014). Hence, these continental basement slices could correspond to extensional allochtons of the hyper-extended continental margin that surrounded the Piemonte-Ligurian ocean (Beltrando et al., 2010; Beltrando et al., 2014; Dal Piaz et al., 2001).

\subsection{A polymetamorphic history}

The protoliths of the Mt. Emilius klippe rocks are pre-alpine in age, and mostly correspond to granitoids and sillimanite-biotite-garnet-plagioclase paragneisses, which include dykes and pegmatitic quartz-plagioclase veins, calc-sillicates, marbles and mafic rocks. The mafic rocks correspond to garnet-clinopyroxene-plagioclase-hornblende granulites and banded gabbros (Dal Piaz et al., 1983; Pennacchioni, 1996). The Mt. Emilius klippe rocks underwent a first stage of metamorphism at medium pressure-high temperature (MP-HT) conditions (i.e., 0.6-0.8 GPa and $700{ }^{\circ} \mathrm{C}$; Dal Piaz et al., 1983; Fig. 1b, point 1). The $M P-H T$ assemblages are preserved as relics similar to those found in the Sesia-Lanzo unit (Dal Piaz et 
al., 1983). This was followed by a first stage of retrogression under amphibolite-facies $P-T$ conditions (Fig. 1b, point 2), prior to the high pressure-low temperature (HP-LT) alpine metamorphism (Dal Piaz et al., 1983).

Rocks of the Mt. Emilius klippe suffered a later alpine tectono-metamorphic overprint, that essentially occurred under HP conditions (Dal Piaz et al., 1983; Pennacchioni, 1996). The $P-T$ conditions of this eclogitic event (Fig. 1b, point 3a) were initially estimated at 1.1-1.3 GPa and $460-470{ }^{\circ} \mathrm{C}$ by Dal Piaz et al. (1983). However, the $P-T$ conditions for the Mt. Emilius eclogites have been re-estimated at 2.15-2.40 GPa and 500-550 ${ }^{\circ} \mathrm{C}$ (Angiboust et al., 2017; see dark star in Fig. 1b). These conditions are consistent with peak pressures of 2.2-2.4 GPa (Angiboust et al., 2009; Fig. 1b, point 3b), 2.1-2.3 GPa (Weber and Bucher, 2015; see dark circle in Fig. 1b) and 2.0-2.5 GPa (Fassner et al., 2016; see square in Fig. 1b) estimated for the underlying Zermatt-Saas ophiolitic unit, the Theodul Glacier unit and the Etirol-Levaz slice, respectively.

The alpine metamorphic evolution was accompanied by polyphased deformations, as attested by various mineral relics and structures (Dal Piaz et al., 1983; Pennacchioni, 1991, 1996). Two main deformation episodes affected the mafic lithologies at eclogite-facies conditions. The first one induced development of foliation parallel to the protolith layering, incomplete transformation of the granulites and ended up by a brittle deformation event that produced veins at eclogite-facies $P-T$ conditions. The second deformation event led to the formation of $S-L$ tectonites and mylonites (according to Pennacchionni, 1996). Salt-rich aqueous fluids infiltrated the rocks during deformation (Scambelluri et al., 1998). These fluids seem to have played a key role during eclogitization of the granulite protoliths, deformation localization and enhanced metamorphic re-equilibration (Pennacchioni, 1996; Angiboust et al., 2017).

Finally, the eclogitic facies assemblages underwent a retrograde overprint, first under 
blueschist conditions and later under greenschist-facies $P-T$ conditions, associated with late alpine exhumation (Bearth et al., 1980; Dal Piaz et al., 1983; Pennacchioni, 1996; Fig.1b, point 4). The late greenschist-facies overprint, of relatively moderate intensity inside the Mt. Emilius unit, is mainly visible in the 100-200 meters basal part of the klippe, i.e., at the contact with the underlying $H P$ ophiolites that belong to the Zermatt-Saas unit.

\section{Sampling strategy and analytical methods}

\subsection{Sampling strategy}

150 samples were collected in the Mt. Emilius klippe (Fig. 1a), from which 75 polished thin sections were made. The samples come from different localities (e.g., Arbolle, Menabreaz, Laures, Bon Plan) and are distributed over the whole klippe (Fig. 1c). In this study, we focus on the Arbolle area, located along the western side of the Mt. Emilius klippe, above the Echo lake (N45 40'6.2"-E007²1'43.8"; Fig. 1c). Indeed, although brittle structures have been observed in other localities, the Arbolle area shows the largest amount of these deformation features and the most complete record of cross-cutting relationships.

\subsection{Scanning electron microscopy and microprobe}

Mineral characterisation, study of their spatial distribution and semi-quantitative chemical analyses were carried out with an Ultra 55 Plus Carl Zeiss Scanning Electron Microscope (SEM) equipped with an energy-dispersive spectrometer and operating at an accelerating voltage of $20 \mathrm{kV}$ at the German Research Centre for Geosciences (GFZ) of Potsdam. The quantification of $\mathrm{Si}, \mathrm{Ti}, \mathrm{Al}, \mathrm{Fe}, \mathrm{Mn}, \mathrm{Mg}, \mathrm{Ca}, \mathrm{Na}$ and $\mathrm{K}$ was performed with a 
JEOL JXA 8230 Electron Probe Micro-Analyser (EPMA) at the GFZ, using $15 \mathrm{kV}$ acceleration voltage, a beam current of $20 \mathrm{nA}$ and a beam diameter of $10 \mu \mathrm{m}$ and the following standards: orthoclase $(\mathrm{Al}, \mathrm{Si}, \mathrm{K})$, rutile $(\mathrm{Ti})$, wollastonite $(\mathrm{Ca})$, albite $(\mathrm{Na})$, periclase $(\mathrm{Mg})$, hematite $(\mathrm{Fe})$ and rhodonite $(\mathrm{Mn})$. X-ray element maps were aquired using a $15 \mathrm{kV}$ acceleration voltage, a beam current of $30 \mathrm{nA}$ and a beam size of $2 \mu \mathrm{m}$.

\subsection{Electron backscatter diffraction}

Crystallographic-preferred orientation (CPO) of HP clinopyroxene was determined via automatic indexation of Electron BackScatter Diffraction (EBSD) patterns (Adams et al., 1993; Prior et al., 1999). Measurements were performed in two samples sectioned normal to the foliation and parallel to the stretching lineation. These thin sections were polished with diamond paste down to a $0.25 \mu \mathrm{m}$ grain size in an alkaline solution of colloidal silica for two hours. The EBSD measurements were conducted using a FEI Quanta 3D FEG dual-beam machine installed at the GFZ, and equipped with an EDAX-TSL EBSD Digiview camera and the OIM/TSL version 5.31 software. Uncoated samples were analysed under low-vacuum conditions of $5 \mathrm{~Pa}$ of $\mathrm{H}_{2} \mathrm{O}$, an accelerating voltage of $20 \mathrm{kV}$, a beam current of $8 \mathrm{nA}$, a working distance of $10 \mathrm{~mm}$ and step sizes of $1 \mu \mathrm{m}$. Post-indexation processing included the standardisation of the confidence index (CI) and the CI correlation between neighbour points, assuming a value of 0.1 . The orientation distribution functions, misorientations and pole figures were calculated and plotted using the MTEX toolbox for Matlab, version 4.2.1 (Hielscher and Schaeben, 2008; Mainprice et al., 2011), considering only measurements with CI > 0.2. All the pole figures were plotted in the tectonic reference frame, with vertical foliations oriented E-W and horizontal lineations in the same direction. 


\section{Field observations and main rock-types}

In the Arbolle area, we observed a large shear zone within the granulites (Fig. 2a), which comprises i) granulite clasts (Fig. 2b) representing undeformed host rock slices, ii) eclogitised and foliated mafic granulites (Fig. 2c), iii) mafic boudins (Fig. 2d), comprising garnet, clinopyroxene, epidote, white micas, quartz, pyrite and calcite, and iv) eclogite breccias (Fig. 2e), composed of garnet, clinopyroxene, and/or epidote broken fragments. The clasts within breccias have variable sizes, are randomly oriented, and generally present a mylonitic foliation. A fine-grained eclogitic matrix formed by clinopyroxene, epidote and garnet envelops the clasts. Breccias crop out as fractured metric boudins, sometimes surrounded by 10-15 centimeters thick layers formed by almost $100 \%$ garnet. These garnetites are fractured, cemented by a first clinopyroxene foliation and embedded, in some places, in a second eclogitic foliation containing clinopyroxene, epidote and garnet (Fig. 2f). All rocktypes are crosscut by different types of $H P$ veins (e.g., garnet or clinopyroxene; Fig. $2 \mathrm{~g}$ ).

\section{Deformation styles and petro-chemical constraints}

The main rock-types and structures observed in the field are here described in more detail, in relationship with the chemical composition of the rock-forming minerals they host (mainly garnet and clinopyroxene, which are ubiquitous in these rocks). Mineral abbreviations are after Whitney and Evans (2010).

\subsection{Eclogitised granulites}

The eclogitised granulites (Fig. 2c) are composed of garnet, clinopyroxene, 
clinozoisite (Tab. 1) and titanite, with lower abundance of calcic amphibole, white mica, chlorite, quartz, calcite, apatite, rutile and pyrite. They are often crosscut by clinozoisite veins (Fig. 3a-b; see section 5.4 for more details).

EPMA analyses carried out on garnet reveal two generations marked by distinct compositions (Fig. 3d). The fractured garnet cores $\left(\right.$ Grt0) are richer in magnesium $\left(X_{P y}=\right.$ 0.43-0.44; Fig. 3d). Their high $X_{M g}$ ratios $\left(X_{M g}=0.52-0.54\right.$; see Tab. A in supplementary material) indicate that garnet grew at high temperatures $\left(\sim 750{ }^{\circ} \mathrm{C}\right.$, calculated using the methods of Ai (1994) and Ravna (2000); see Tab. C in supplementary material). Garnet rims (Grt1), also found as smaller idiomorphic garnet grains in the clinopyroxene-rich matrix, present a lower $\mathrm{Mg}$ content $\left(X_{P y}=0.06-0.39\right.$; Fig. 3d). Such a low $X_{M g}$ ratio $\left(X_{M g}=0.10-0.48\right.$; see Tab. A in supplementary material) suggests growth at lower temperature than Grt0 ( 550 ${ }^{\circ} \mathrm{C}$; see Tab. C in supplementary material). From Grt0 to Grt1, the concentration changes are sharp, with decreasing $\mathrm{Mg}$ content while the $\mathrm{Fe}$, $\mathrm{Ca}$ and $\mathrm{Mn}$ contents increase (Fig. 3d; see also Angiboust et al., 2017).

Two different types of clinopyroxene can be identified microscopically, according to the occurrence of titanite inclusions. They have a composition ranging between diopside (Di 100-Jd 0) and omphacite (Di 50-Jd 50, see Fig. 3d and Tab. B in the supplementary material).

\subsection{Eclogitic breccias}

The eclogitic breccias are composed of garnetite clasts cemented by clinopyroxene (Fig. 4a). At the microscopic scale, the garnetite clasts show an internal foliation formed by clinopyroxene (HPCpxl) and clinozoisite (Czol), and are embedded in an external foliation (Fig. 4b) also composed of clinopyroxene ( $H P$ Cpx2) and clinozoisite $(C z o 2)$, and characterised by a different orientation compared to the older foliation (Fig. 4b-c). 
Chemical analyses carried out on garnet (see Tab. 1 and Tab. A in supplementary material) from garnetite clasts reveal a single generation of garnet (Grt1) with homogeneous $X_{M g}$ ratios, but highly variable $\mathrm{Ca}$ abundances $\left(X_{G r o}=0.43-0.94 ;\right.$ Fig. $\left.4 \mathrm{~d}\right)$. Garnet crystals from garnetite clasts are sometimes fractured and cemented by a newer garnet generation characterised by slightly higher Fe, Mn and Mg contents, and lower Ca contents (Fig. 4d). The chemical analyses performed in clinopyroxene from garnetite clasts reveal two clusters with different composition (Tab. 1). The first one corresponds to diopside compositions $\left(X_{D i}=\right.$ $0.76-1, X_{J d}=0-0.24, X_{A e}=0-0.13$; left Fig.4d, Tab. B in supplementary content) and the second one corresponds to omphacite compositions in the Morimoto (1988) classification $\left(X_{D i}\right.$ $=0.52-0.57, X_{J d}=0.39-0.48, X_{A e}=0-0.09$; right Fig. $4 \mathrm{~d}$, Tab. B in supplementary material).

We carried out EBSD crystallographic orientation measurements on clinopyroxene occurring as an interstitial phase in a garnetite clast (Fig. 4e). The poles (100) of the clinopyroxene are distributed along a discontinuous band parallel to the foliation, with two maxima parallel to $\mathrm{X}$ and Y, whereas the poles of (010) and (001) are concentrated at low angles from the lineation and pole of the foliation, respectively (Fig. 4f). The misorientation angle distribution shows a major peak for low misorientation angles from 2 to $5^{\circ}$, followed by minor peaks with higher misorientation angles (Fig. 4g). Although only determined on a few clinopyroxene grains in this sample (clinopyroxene is a minor phase here), the CPO appears to be very strong. The major peaks for low misorientation angles either indicate that clinopyroxene crystallised with a slightly distorted lattice, or that the grains were reworked, since they display evidence of minor amounts of crystal plasticity after crystallisation. Note that similarly to $\mathrm{CPO}$, the occurrence of most peaks at low misorientation angles could also be related to the limited number of pyroxene crystals analysed in this sample. 


\subsection{Eclogitic foliation surrounding eclogite breccias}

The eclogite clasts are embedded in a metamorphic foliation composed of clinopyroxene, clinozoisite and garnet (Fig. 5a, Tab. 1) and developed in the eclogite-facies $P$ $T$ conditions. At the microscopic scale, the clinopyroxene grains defining this foliation are stretched and rotated (Fig. 5b-c-e). Chemical analyses performed on garnet crystals that are part of this foliation reveal only one type of garnet composition (Grtl; Fig. 4d, Tab. A in supplementary material). Analyses performed on clinopyroxene display two clusters with different chemical compositions. The first one corresponds to diopside compositions $\left(\mathrm{X}_{D i}=\right.$ $0.82-1, \mathrm{X}_{J d}=0-0.18$; left Fig.4d, Tab. B in supplementary material) and the second one to omphacite compositions $\left(\mathrm{X}_{D i}=0.53-0.56, \mathrm{X}_{J d}=0.44-0.47\right.$; right Fig.4d, Tab. $\mathrm{B}$ in supplementary material).

EBSD crystallographic orientation measurements have been conducted along this pervasive eclogitic foliation, where clinopyroxene occurs as discontinuous bands interleaved with garnet and/or clinozoisite-rich bands (Fig. 5e). The intensity of the CPO is moderate. The poles of (100) are distributed along a broad band normal to the foliation and with a maximum concentration at low angles to the pole of the foliation. The poles of (001) are also spread along a continuous band, this time sub parallel to the foliation and with maxima lying at low angles to the lineation of reference. The poles of (010) are poorly aligned (Fig. 5f). The misorientation angle between clinopyroxene neighbour crystals displays a small peak for low misorientation angles (i.e., $2-5^{\circ}$ ) and otherwise an almost normal distribution of misorientation angles that tend to follow the uncorrelated and random distribution lines (Fig. $5 \mathrm{~g})$ 


\subsection{Vein types}

Different veins types (i.e., garnet-, clinopyroxene-, clinozoisite- chlorite- and calciterich veins) have been observed at various spatial scales (i.e., from outcrop to thin section scale). Macroscopic clinopyroxene veins crosscut the eclogitic foliation (Fig. 6a) and are composed of clinopyroxene, clinozoisite and garnet. Clinopyroxene filling fractures does not show any growing preferential orientation (minerals can be parallel, perpendicular or randomly oriented compared to the edges of the fractures). Clinozoisite veins, in which white micas can be also found, cut through the eclogitised granulite (Fig. 3a). In these clinozoisite veins, undeformed, perfectly rhombic sections are well identifiable (Fig. 3b). These sections are now replaced by clinozoisite and white micas, suggesting that these sections correspond to lawsonite pseudormorphs. In garnetite clasts, clinopyroxene veins are crosscut by both clinozoisite veins and chlorite veins (Fig. 6b). Garnetite clasts are also crosscut by calcite veins (Fig. 6c; Angiboust et al., 2017). These various vein families do not exhibit any preferential orientation.

Garnet veins cut through clinopyroxene crystals (Fig. 6d). Clinopyroxene veins have also been identified (Fig. 6e), sometimes associated with clinozoisite. The chemical analyses carried out on garnet and clinopyroxene veins reveal homogeneous garnet compositions (Grt1; Fig. 6f, Tab. A in supplementary material) and clinopyroxene compositions ranging from diopside to omphacite (Fig. 6f, Tab. B in supplementary material). Vein-type garnet shows minor internal chemical variations, in Fe content for example (Fig. 6f).

\section{Implications for the tectono-metamorphic history of the Mt. Emilius eclogites}


Based on our petro-structural analyses associated with both micro-chemical and EBSD data, we propose a model for the tectono-metamorphic history of the eclogites from the Arbolle shear zone located at the base of the Mt. Emilius klippe. This model highlights the link between the $P$ - $T$ history, the deformation processes and the fluid circulations that possibly led to the formation of the brecciated eclogites of the Arbolle region. This model is presented in figure 7.

\subsection{Age of the eclogite deformation}

Before going further into the description of the deformation, it is important to first clarify its age: i) in the eclogitic structures, pre-alpine garnet crystals have not been clearly identified. Our chemical analyses (section 5) show that all garnet crystals growing in breccias, along the foliation and in veins, are Grtl type, which thus crystallised during the alpine stage. ii) Most of clinopyroxene crystals are HP clinopyroxene crystals (see Angiboust et al., 2017), and, therefore, also formed during the alpine stage. The composition of both diopside and omphacite can be analysed within a single grain without any real structural difference: some grains have diopside-rich cores and omphacite-rich rims but the opposite is also observed. The presence of diopside instead of omphacite at $H P$ could be due to the high calcium concentrations present in these rocks (Angiboust et al., 2017). iii) Associated diopside- and omphacite are indifferently observed in fractures cutting through alpine garnetite clasts (see section 5.2; Fig. 4a), parallel to the alpine foliation embedding these clasts (Fig. 5a-b-c), or even, in fractures cutting through this latter foliation (Fig.6 a). iv) The CPO obtained for $H P$ clinopyroxene, which does not require $H T$ conditions (Piepenbreier and Stöckhert, 2001), is caused by ductile deformation in eclogite-facies $P-T$ conditions. v) Finally, brittle events implying $H P$ clinopyroxene also occurred during this stage. This is evidenced by clasts of $H P$ clinopyroxene, which present the same chemical compositions than those from the eclogitic 
foliation (see section 5.2, Fig. 5d-6d-f, Tab. 1, Angiboust et al., 2017). Therefore, even if prealpine deformation and mineral relics (i.e., garnet and clinopyroxene) may be preserved in the host granulite (Fig. 3), the brittle and ductile deformations observed in the eclogites from the Arbolle region, and summarised in figure 7, are undoubtedly related to the alpine orogeny. The deformation occurred close to the $H P-L T$ metamorphic peak in the lawsonite-eclogite facies $P-T$ conditions and in successive steps summarised as:

\subsection{Eclogitisation and fluid-rock interaction (t1)}

In the eclogite-facies $P-T$ conditions, garnetite layers formed at the interface between mafic boudins and granulites. Considering the presence of heterogeneous chemical zoning in garnet (e.g., Fig. 4d) as well as the entrapment of oriented HP clinopyroxene inclusions (Fig. 4b-c), garnetite layers probably resulted from fluid-rock interaction processes during deformation. The rheological contrast existing at the interface between mafic boudins and the host granulite could be responsible for a preferential localisation of deformation, which could have been initiated by a first fracturing event that then allowed pumping of fluids.

In some mafic boudins, eclogitic banding (alternation of garnetite and clinopyroxenite layers; Fig. 2a-g) attests to a rather intense ductile deformation leading to the formation of mylonitic eclogites. A foliation is also present and defined by the HP clinopyroxene in garnetite layers. The CPO patterns observed in the HP clinopyroxene (Fig. 4f), together with predominant low misorientation angles (Fig. 4g), probably results from orientated growth under tectonic stress in $H P-L T$ conditions.

\subsection{Formation of eclogite clasts by fracturing event ( $t 2)$}


The more or less layered eclogitised mafic boudins and the associated garnetite levels (when present) are locally fractured as evidenced by the presence of $H P$ clinopyroxene and/or garnet fractures (Fig. 2f-g and 4a). Such brittle behaviour is also observed at the microscopic scale where fractured garnet (Fig. 4d) and fractured $H P$ clinopyroxene (Fig. 6d) are sealed by alpine minerals.

\subsection{Ductile deformation and eclogitic breccias evolution (t3)}

The eclogite clasts, which are in some places layered (Fig. 2a-g), form boudins embedded in an eclogitic foliation defined by HP clinopyroxene, clinozoisite and garnet (Fig. $2 \mathrm{f}$ and 5a). The foliation around the clasts (Fig. 5b-c) indicates a ductile deformation process also described by Dal Piaz et al. (1983), Pennacchionni (1996) and Scambelluri et al. (1998). The CPO patterns observed in HP clinopyroxene crystals (Fig. 5f) are very close in shape and intensity to the omphacite CPO patterns from other alpine eclogites (e.g., Bascou et al., 2001). As demonstrated by Bascou et al. (2001) and Godard and Van Roermund (1995), omphacite CPO patterns are normally related to the strain regime. Considering the above alignment and comparison between natural examples and numerical modelling results (Bascou et al,. 2002), our HP clinopyroxene CPO probably results from LS-type strain regime (Helmstaedt et al., 1972), with foliation and lineation relatively well developed (Fig. 5f). This is in agreement with field evidence and microstructures (e.g., Fig. 5b-c-e). The fabric is also slightly oblique with respect to the main reference frame (foliation/lineation), suggesting a component of noncoaxial deformation during the CPO development (e.g., Abalos, 1997). The presence of undulose extinction and subgrain boundaries in the $H P$ clinopyroxene, coupled with the low misorientation angles observed in the histogram (Fig. 5g), both suggest that deformation was mainly accommodated by intra-crystalline plasticity. Assuming a predominant slip system 
where the slip plane aligns with the flow plane and the slip direction with the flow direction (e.g., Nicolas and Poirier, 1976), then the main slip system in the $H P$ clinopyroxene during ductile deformation was [001] (100).

\subsection{New fracturing events and formation of HP veins (t4)}

Both the elements within the shear zone (i.e., boudins and clasts) and the eclogitic foliation (presented above; $t 3$ ) are crosscut by HP clinopyroxene veins (Fig. 6a), attesting to a brittle event after ductile deformation ( $t 3)$. Furthermore, the co-stability of garnet and clinozoisite in these veins (t4) indicates that these two minerals grew under the same $P-T$ conditions as the ductile deformation event $(t 3)$. Clinozoisite veins cut through all the structures described above (Fig. 2c, 3a and 6b). These veins include brown rhombic mm-sized crystals of clinozoisite associated with white micas, interpreted as lawsonite pseudomorphs (Fig. 3b). This would imply that these veins, corresponding to former lawsonite veins, were formed in the lawsonite-bearing eclogite field close to $P-T$ conditions of the metamorphic peak. Finally, calcite is present either as veins (Fig. 6c) or in the matrix in direct contact with garnetite boudins and clasts. The fact that all these veins have different chemical compositions (Fig. 6), and that they include garnet and HP clinopyroxene zoning patterns (Fig. 4d and 6f), point to the existence of multiple fracturing/healing events in the presence of a fluid phase during deformation at HP-LT conditions that involved a cyclic repetition of the phases $t 3$ and t4.

\section{Implications for the deformation of rocks in subduction zones and the role of fluids}

This study confirms the importance of brittle deformation processes during 
metamorphism at $H P$-LT conditions. The tectono-metamorphic history proposed here shows that the rocks from the Mt. Emilius klippe underwent successive switches between brittle and ductile deformation at (or close to) the metamorphic peak pressure, in the lawsonite-eclogite facies $P-T$ conditions. This example, close to peak metamorphic conditions, allows us to discuss i) possible processes leading to such a dual deformation mode at depth, along the subduction interface as well as ii) the role of fluids, which are indubitably present in this case.

\subsection{Brittle behaviour during eclogite-facies metamorphism}

In subduction zones, brecciation and formation of $H P$ fractures could be explained via different processes that could be either external (i.e., related to the tectonic stresses) or internal (i.e., linked to the intrinsic properties of eclogites). When buried under $H P-L T$ conditions, rocks undergo high shear stresses linked to subduction dynamics. At the onset of exhumation, when the metamorphic units detach from the subducting slab, the state of stresses sustained by the rocks changes (Yamato and Brun, 2017). This switch could be responsible for fracturing at depth and could possibly lead to breccias formation (e.g., Angiboust et al., 2012; Godard and Van Roermund, 1995; Van Roermund and Boland, 1981). However, these clasts formed during brecciation do not systematically show large displacements (Fig. 2f), and the $H P$ clinopyroxene, lawsonite and calcite-filled fractures present random orientations (Fig. 6). Yet, the clasts may have been quickly sealed by matrix garnet or $H P$ clinopyroxene that would have prevented their mutual displacements and frozen the post-brecciation texture. If the evolution and the amount of shearing remain difficult to estimate, differential stress was high enough for failure criteria to be met. Furthermore, shearing appears to have been non-negligible as evidenced by differential rotation of the mafic clasts and development of the eclogitic foliation both within the clasts and wrapping around the clusters of clasts. 
To trigger fracturing, the eclogitisation process itself can also be invoked (e.g., Bjornerud et al., 2002, Philippot \& Van Roermund, 1992). The modification of chemical and physical properties of the buried material significantly affects how rocks respond to stress at depth. In particular, the progressive eclogitisation, which is assisted by deformation and fluid infiltration leads to mineralogical changes. The consequence of this could affect subduction zone dynamics by modifying both the density and the rheology of the progressively subducting crustal material (e.g., Austrheim and Engvik, 1997). The associated volume change can then be large enough to generate stresses allowing fracturing (e.g., Jamtveit et al., 2016). However, even if local stresses during metamorphic reactions may be high and cause localised fracturing, the amount of eclogitic mafic rocks observed in this area is very low (see Fig. 1c). Consequently, even though the amount of stress variations due to volume changes should not be neglected, especially during formation of the thick garnetite layer (i.e., at the onset of the eclogitisation, stage $t 1$ ), it does not seem to be the key process at the scale of the entire Mt. Emilius klippe.

\subsection{Role of fluids at eclogite-facies conditions}

Fluid circulation along the subduction interface need to be considered because it enhances strain localisation and critically controls the rheology of rocks (e.g., Angiboust et al., 2015; Austrheim and Engvik, 1997; Bjornerud et al., 2002; Hacker et al., 2003). On the one hand, it has been shown that fluid release during prograde breakdown of hydrous minerals with increasing temperature may generate brittle features such as veins (e.g., Gao et al., 2007; Philippot and Selverstone, 1991) and tectonic breccias (e.g., Angiboust et al., 2012). In particular, fluids can be responsible for an increase of internal fluid pressure, leading to brittle deformation by hydro-fracturing processes (e.g., Davies, 1999; Healy et al., 2009). Fluids can thus be responsible for the switch from ductile to brittle behaviour as we 
observed in the Mt. Emilius area. On the other hand, fracturing allows the pumping and the localisation of fluid circulation (e.g., Sibson, 1981, Mancktelow, 2006). This process could then help for the re-equilibration of the pre-alpine minerals during the alpine tectonometamorphic events (Austrheim et al., 1996) and facilitate, by strain weakening, ductile deformation between two brittle events. Hence, a fundamental problem that remains to be solved, and that is common to all subduction zones interfaces worldwide, is how to decipher if fluids induced fracturing or, alternatively, if fracturing is responsible for fluid circulation. The Mt. Emilius case study provide important insights to discuss this point because, whether they are a cause or a consequence of the deformation, fluids play an important role in this system.

Fracturing triggered by high fluid overpressure requires the production or arrival of fluids in a volume of rocks that is sealed by a sufficiently impermeable cap. In our case, fluids were probably initially absent because the Mt. Emilius unit is dry (mainly made of granulites). The main source that can provide an important amount of fluid is the oceanic Zermatt-Saas unit located just below the Mt. Emilius tectonic slice (Fig. 1). The main question that arises is the significance of the numerous vein systems that are ubiquitous within the Mt. Emilius klippe. While they can reflect the presence of lithostatic to transient supra-lithostatic pore fluid pressures, it remains unsure how these fluids percolated through the Mt. Emilius klippe massif. Hydro-fracturing of the hanging wall (Davies, 1999) or propagation of porosity waves (e.g., Connolly, 2010) could be envisioned as possible processes. Alternatively, breccias formation and creation of porosity along the Arbolle shear zone may have enabled fluid pumping, channelizing various chemical contributions from the subduction interface region. By considering that the influx of fluid is, initially, linked to a fracturing event triggered by an increase of differential stresses, it is possible to reconcile all our observations. The composition of the fluids pumped during each fracturing event could vary, depending on the 
pathways followed by fluids through the rocks. All the processes mentioned above (i.e., metamorphic reactions and their rheological impact) can then be activated afterwards and self-maintained by the introduction of fluids in the system.

\section{Conclusion}

This study provides new field evidence shedding light on deformation processes that occur along the subduction interface in $H P-L T$ conditions. The structural record observed here is of key importance because it witnesses of processes associated with slicing of metamorphic units at the metamorphic peak from a downgoing slab in a subduction zone. Understanding the significance of $H P$ brittle deformation at eclogite-facies metamorphic conditions thus paves the way for further rheological and geophysical studies focused on mechanical processes rooted in the plate interface region of subduction zones. We have shown here, that ductile behaviour is not the only rule at eclogite-facies conditions as multiple successive brittle events can exist. These findings highlight the fact that lithological heterogeneities (such as mafic dykes or sills, for instance) are important since they facilitate the localisation of the deformation as well as fluid channelling. We suggest that embrittlement of the Arbolle shear zone was triggered by strain rate increase along the subduction interface possibly under lithostatic pore fluid pressure conditions. Enhanced fluid channelization enables then metamorphic reaction to proceed, leading to volume change and further fracturing. Nevertheless, all these observations raise the more general question of how pervasive fluid circulations initiated in an initially dry rocks, pervasively metamorphosed, when clear localised drains connecting the different garnetite- and breccia-bearing mafic lenses are not observed. This therefore raise the need to i) better understand the complex link between fluid circulation, eclogitisation and deformation localization under $H P-L T$ conditions and to ii) 
decipher whether the brecciation reported here occurred at seismic strain rates. Further documentation of similar natural examples will help better imaging deep fault zones and improve our understanding of the origin of intermediate-depth seismicity in subduction zones.

\section{Acknowledgements}

M.A. Smit and an anonymous reviewer are highly thanked for their thoughtful comments and suggestions that greatly improved the quality of the manuscript. K. Joy, J. Lehmann and R. Tartèse are also highly thanked for style checking. The authors thank the INSU SYSTER program that funded a part of this work. LFGM and SA thank the GFZ for the financial support for fieldwork. This is IPGP contribution \#38XX. 


\section{References}

Abers, G.A., van Keken, P.E., Kneller, E.A., Ferris, A., Stachnik, J.C., 2006. The thermal structure of subduction zones constrained by seismic imaging: Implications for slab dehydration and wedge flow. Earth and Planetary Science Letters, 241(3), 387-397.

Abalos, B., 1997. Omphacite fabric variation in the Cabo Ortegal eclogite (NW Spain): relationships with strain symmetry during high-pressure deformation. J. Struct. Geol. $19,621-637$.

Adams B.L., Wright S.I., Kunze, K., 1993. Orientation imaging: the emergence of a new microscopy. Metallurgical Transactions A 24:819-831

Angiboust, S., Agard, P., Jolivet, L., Beyssac, O., 2009. The Zermatt-Saas ophiolite: the largest (60-km wide) and deepest (c. 70-80 km) continuous slice of oceanic lithosphere detached from a subduction zone?. Terra Nova, 21(3), 171-180.

Angiboust, S., Agard, P., Raimbourg, H., Yamato, P., Huet, B., 2011. Subduction interface processes recorded by eclogite-facies shear zones (Monviso, W. Alps). Lithos, 127(1), 222-238.

Angiboust, S., Agard, P., Yamato, P., Raimbourg, H., 2012. Eclogite breccias in a subducted ophiolite: a record of intermediate-depth earthquakes?. Geology, 40, p. 707-710.

Angiboust, S., Kirsch, J., Oncken, O., Glodny, J., Monié, P., and Rybacki, E., 2015. Probing the transition between seismically coupled and decoupled segments along an ancient subduction interface. Geochemistry, Geophysics, Geosystems, 16(6), 1905-1922.

Angiboust, S., Yamato, P., Hertgen, S., Hyppolito, T., Bebout, G. E., and Morales, L., 2017. Fluid pathways and high pressure metasomatism in a subducted continental slice (Mt. Emilius klippe, W. Alps). Journal of Metamorphic Geology, in press.

Ai, Y., 1994. A revision of the garnet-clinopyroxene $\mathrm{Fe}^{2+}-\mathrm{Mg}$ exchange 
geothermometer. Contributions to Mineralogy and Petrology, 115(4), 467-473.

Austrheim, H., Boundy, T.M., 1994. Pseudotachylytes generated during seismic faulting and eclogitization of the deep crust. Science, 265(5168), 82-83.

Austrheim, H., Erambert, M., Boundy, T.M., 1996. Garnets recording deep crustal earthquakes. Earth and Planetary Science Letters, 139(1), 223-238.

Austrheim, H., Engvik, A.K., 1997. Fluid transport, deformation and metamorphism at depth in a collision zone. In: Fluid flow and transport in rocks: mechanisms and effects. Ed: B. Jamtveit \& B.W.D. Yardley. Chapman \& Hall, 123-138

Austrheim, H., Erambert, M., Engvik, A.K., 1997. Processing of crust in the root of the Caledonian continental collision zone: the role of eclogitization. Tectonophysics, 273(1), 129-153.

Austrheim, H., Andersen, T.B., 2004. Pseudotachylytes from Corsica: fossil earthquakes from a subduction complex. Terra nova, 16(4), 193-197.

Ballèvre, M., Kienast, J.R., Vuichard, J.P., 1986. La «nappe de la Dent-Blanche» (Alpes occidentales): deux unités austroalpines indépendantes. Eclogae Geologicae Helvetiae, 79(1), 57-74.

Bascou, J., Barruol, G., Vauchez, A., Mainprice, D., Egydio-Silva, M., 2001. EBSD-measured lattice-preferred orientations and seismic properties of eclogites. Tectonophysics, 342(1), 61-80.

Bascou, J., Tommasi, A., Mainprice, D., 2002. Plastic deformation and development of clinopyroxene lattice preferred orientations in eclogites. Journal of Structural Geology, 24(8), 1357-1368.

Bearth, P., Dal Piaz, G.V., Elter, G., Gosso, G., Nervo, R., 1980. Il lembo di ricoprimento del Monte Emilius, Dent Blanche s.l. Osservazioni preliminari, Acad. Sci. Torino Mem., $144,227-241$ 
Beltrando, M., Rubatto, D., Manatschal, G., 2010. From passive margins to orogens: the link between ocean- continent transition zones and (ultra-)high-pressure metamorphism, Geology, 38, 559-562.

Beltrando, M., Manatschal, G., Mohn, G., Dal Piaz, G.V., Brovarone, A.V., Masini, E., 2014. Recognizing remnants of magma-poor rifted margins in high-pressure orogenic belts: The Alpine case study. Earth-Science Reviews, 131, 88-115.

Bjørnerud, M.G., Austrheim, H., Lund, M.G., 2002. Processes leading to eclogitization (densification) of subducted and tectonically buried crust. Journal of Geophysical Research: Solid Earth, 107(B10).

Brace, W.F., Kohlstedt, D.L., 1980. Limits on lithostatic stress imposed by laboratory experiments. Journal of Geophysical Research, v. 85, p. 6248-6252.

Brodie, K.H., Rutter, E.H., 1987. Deep crustal extensional faulting in the Ivrea Zone of northern Italy. Tectonophysics, 140(2), 193-212.

Compagnoni, R., 1977. The Sesia-Lanzo Zone: high pressure-low temperature metamorphism in the Austroalpine continental margin, Rend. Soc. Ital. Mineral. Petrol, 33, 335-374.

Connolly, J.A.D., 2010. The mechanics of metamorphic fluid expulsion. Elements, 6(3), 165172.

Dal Piaz, G.V., Nervo, R., 1971. Il lembo di ricoprimento del Glacier-Rafray (Dent Blanche 1s). Bollettino della Società Geologica Italiana, 90(4), 401-414.

Dal Piaz, G.V., Gosso, G., Lombardo, B., 1983. Metamorphic evolution of the Mt. Emilius klippe, Dent Blanche nappe, western Alps.

Dal Piaz, G.V., 1999. The Austroalpine-Piedmont nappe stack and the puzzle of Alpine Tethys, Mem. Sci. Geol. Padova, 51, 155-176.

Dal Piaz, G., Cortiana, G., Del Moro, A., Martin, S., Pennacchioni, G., Tartarotti, P., 2001. Tertiary age and paleostructural inferences of the eclogitic imprint in the Austroalpine 
outliers and Zermatt-Saas ophiolite, western Alps.International Journal of Earth Sciences, 90(3), 668-684.

Dal Piaz, G.V., Gianotti, F., Monopoli, B., Pennacchioni, G., Schiavo, A., Tartarotti, P., 2010. Foglio 091 Chatillon e note illustrative. Carta Geologica d'Italia alla scala 1:50.000

Davies, J.H., 1999. The role of hydraulic fractures and intermediate-depth earthquakes in generating subduction-zone magmatism, Nature, v. 398, p. 142-145.

Engvik, A.K., Austrheim, H., Erambert, M., 2001. Interaction between fluid flow, fracturing and mineral growth during eclogitization, an example from the Sunnfjord area, Western Gneiss Region, Norway. Lithos, 57(2), 111-141.

Fassmer, K., Obermüller, G., Nagel, T. J., Kirst, F., 2016. High-pressure metamorphic age and 691 significance of eclogite-facies continental fragments associated with oceanic lithosphere in the 692 Western Alps (Etirol-Levaz Slice, Valtournenche, Italy). Lithos, 252, 145-159.

Gao, J., John, T., Klemd, R., Xiong, X., 2007. Mobilization of Ti-Nb-Ta during subduction: evidence from rutile-bearing dehydration segregations and veins hosted in eclogite, Tianshan, NW China. Geochimica et Cosmochimica Acta, 71(20), 4974-4996.

Godard, G., Van Roermund, H.L.M., 1995. Deformation-induced clinopyroxene from eclogites. Journal of Structural Geology 17, 1425-1443.

Hacker, B. R., Peacock, S.M., Abers, G.A., Holloway, S.D., 2003. Subduction factory 2. Are intermediate-depth earthquakes in subducting slabs linked to metamorphic dehydration reactions?. Journal of Geophysical Research: Solid Earth, 108(B1).

Handy, M.R., Brun, J.P., 2004. Seismicity, structure and strength of the continental lithosphere. Earth and Planetary Science Letters, 223(3), 427-441.

Healy, D., Reddy, S.M., Timms, N.E., Gray, E.M., Brovarone, A.V., 2009. Trench-parallel fast axes of seismic anisotropy due to fluid-filled cracks in subducting slabs, Earth and 
Planetary Science Letters, 283, p. 75-86.

Helmstaedt, H., Anderson, O.L., Gavasci, A.T., 1972. Petrofabric studies of eclogite, spinelwebsterite, and spinel-lherzolite xenoliths from kimberlite-bearing breccia pipes in southeastern Utah and northeastern Arizona. J. Geophys. Res. 77, 4350 - 4365.

Hielscher, R., Schaeben, H., 2008. A novel pole figure inversion method: specification of the MTEX algorithm. Journal of Applied Crystallography 41, 1024-1037. http:// dx.doi.org/10.1107/S0021889808030112.

Hobbs, B. E., Ord, A., Teyssier, C., 1986. Earthquakes in the ductile regime?. Pure and Applied Geophysics, 124(1-2), 309-336.

Jamtveit, B., Austrheim, H., Putnis, A., 2016. Disequilibrium metamorphism of stressed lithosphere. Earth-Science Reviews, 154, 1-13.

John, T., Schenk, V., 2003. Partial eclogitization of gabbroic rocks in a late Precambrian subduction zone (Zambia): prograde metamorphism triggered by fluid infiltration. Contributions to Mineralogy and Petrology, 146(2), 174-191.

John, T., Schenk, V., 2006. Interrelations between intermediate-depth earthquakes and fluid flow within subducting oceanic plates: Constraints from eclogite facies pseudotachylytes, Geology, 34, 557-560.

Lund, M.G., Austrheim, H., 2003. High-pressure metamorphism and deep-crustal seismicity: evidence from contemporaneous formation of pseudotachylytes and eclogite facies coronas. Tectonophysics, 372(1), 59-83.

Mainprice, D., Hielscher, R., Schaeben, H., 2011. Calculating anisotropic physical properties from texture data using the MTEX open-source package. Geological Society, London, Special Publications, 360(1), 175-192.

Mancktelow, N.S., 2006. How ductile are ductile shear zones? Geology, 34, 345-348.

Mancktelow, N.S., 2009. Fracture and flow in natural rock deformation. Trabajos de geología, 
29(29).

Morimoto, N., 1988. Nomenclature of pyroxenes. Mineralogy and Petrology, 39(1), 55-76.

Nicolas, A., Poirier, J.P., 1976. Crystalline Plasticity and Solid State Flow in Metamorphic Rocks. Wiley, New York.

Passchier, C.W., 1984. The generation of ductile and brittle shear bands in a low-angle mylonite zone. Journal of Structural Geology, 6(3), 273-281.

Pennacchioni, G., 1991. Evoluzione strutturale del M. Emilius (Austroalpino, Alpi occidentali). Rend. Soc. Geol. It.14, 97-100.

Pennacchioni, G., 1996. Progressive eclogitization under fluid-present conditions of preAlpine mafic granulites in the Austroalpine Mt Emilius Klippe (Italian Western Alps). Journal of Structural Geology, 18(5), 549-561.

Pennacchioni, G., Cesare, B., 1997. Ductile-brittle transition in pre-Alpine amphibolite facies mylonites during evolution from water-present to water-deficient conditions (Mont Mary nappe, Italian Western Alps). Journal of Metamorphic Geology, 15(6), 777-791.

Pennacchioni, G., 2005. Control of the geometry of precursor brittle structures on the type of ductile shear zone in the Adamello tonalites, Southern Alps (Italy). Journal of Structural Geology, 27(4), 627-644.

Pennacchioni, G., Mancktelow, N. S., 2007. Nucleation and initial growth of a shear zone network within compositionally and structurally heterogeneous granitoids under amphibolite facies conditions. Journal of Structural Geology, 29(11), 1757-1780.

Philippot, P., Selverstone, J., 1991. Trace-element-rich brines in eclogitic veins: implications for fluid composition and transport during subduction. Contributions to Mineralogy and Petrology, 106(4), 417-430.

Philippot, P., van Roermund, H.L., 1992. Deformation processes in eclogitic rocks: evidence for the rheological delamination of the oceanic crust in deeper levels of subduction 
zones. Journal of structural geology, 14(8), 1059-1077.

Piepenbreier, D., Stöckhert, B., 2001. Plastic flow of omphacite in eclogites at temperatures below $500 \mathrm{C}$-implications for interplate coupling in subduction zones. International Journal of Earth Sciences, 90(1), 197-210.

Prior D.J., Boyle, A.P., Brenker, F., Cheadle, M.C., Austin, D., Lopez, G., Peruzzo, L., Potts, G.J., Reddy, S., Spiess, R., Timms, N.E., Trimby, P.W., Wheeler, J., Zetterström, L., 1999. The application of electron backscatter diffraction and orientation contrast imaging in the SEM to textural problems in rocks. American Mineralogist 84, 17411759.

Ranalli, G., Murphy, D.C., 1987. Rheological stratification of the lithosphere. Tectonophysics, $132,281-295$.

Ravna, K., 2000. The garnet-clinopyroxene Fe2+-Mg geothermometer: an updated calibration. Journal of metamorphic Geology, 18(2), 211-219.

Rietbrock, A., Waldhauser, F., 2004. A narrowly spaced double-seismic zone in the subducting Nazca Plate. Geophysical Research Letters, 31(10).

Scambelluri, M., Pennacchioni, G., Philippot, P., 1998. Salt-rich aqueous fluids formed during eclogitization of metabasites in the Alpine continental crust (Austroalpine Mt. Emilius unit, Italian western Alps). Lithos, 43(3), 151-167.

Segall, P., Simpson, C., 1986. Nucleation of ductile shear zones on dilatant fractures. Geology, 14(1), 56-59.

Sibson, R. H., 1981. Fluid flow accompanying faulting: field evidence and models. Earthquake prediction, 593-603.

Simpson, C., 1985. Deformation of granitic rocks across the brittle-ductile transition. Journal of Structural Geology, 7(5), 503-511.

Van Roermund, H.L.M., Boland, J.N., 1981. The dislocation substructures of naturally 
deformed omphacites. Tectonophysics 78,403-418.

Weber, S., Bucher, K., 2015. An eclogite-bearing continental tectonic slice in the ZermattSaas high-pressure ophiolites at Trockener Steg (Zermatt, Swiss Western Alps). Lithos, 232, 336-359.

Whitney, D. L., and Evans, B. W., 2010. Abbreviations for names of rock-forming minerals. American Mineralogist, 854, 95(1), 185.

Yamato, P., Brun, J.P., 2017. Metamorphic record of catastrophic pressure drops in subduction zones. Nature Geoscience, 10(1), 46-50. 


\section{Figures}

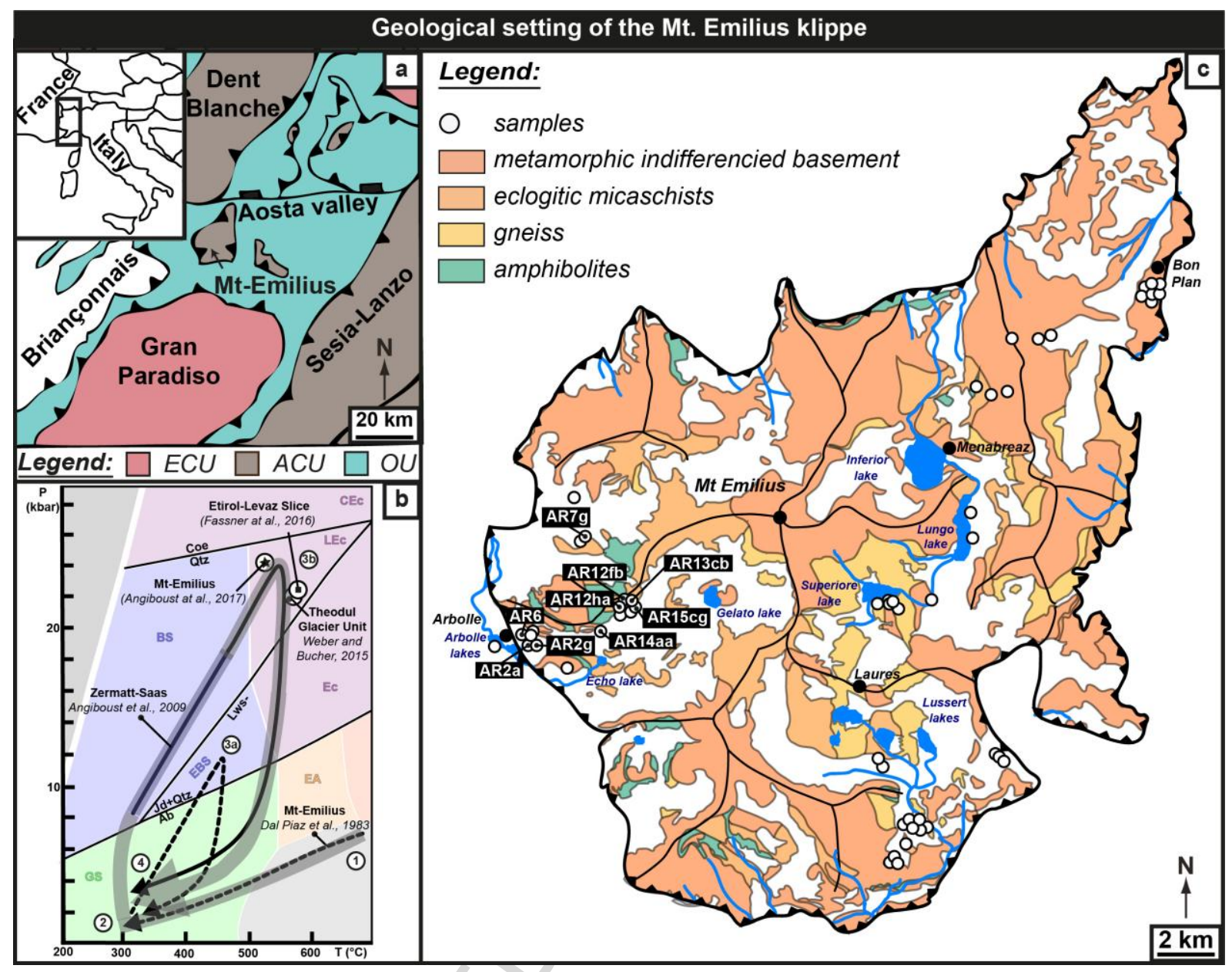

Figure 1: a) Simplified geological map of the Western Alps showing the study area (ECU, European Continental Units; ACU, Austro-alpine Continental Units; OU, Oceanic units). b) Pressure-Temperature diagram showing a compilation of published $P-T$ paths (dashed line: Mt. Emilius klippe, Dal Piaz et al., (1983), solid line: Zermatt-Saas zone, Angiboust et al., (2009)), and of peak $P-T$ conditions (dark circle: Theodul Glacier unit, Weber and Bucher, (2015), dark square: Etirol-Levaz Slice unit, Fassmer et al., (2016), dark star: Mt-Emilius unit, Angiboust et al., (2017)). The wide grey path represent the $P-T$ path considered in this study for the Mt. Emilius klippe. Thin dark lines correspond to main mineral reactions. (Abbreviations: Ab, Albite; Jd, Jadeite; Qtz, Quartz; Coe, Coesite; Lws, lawsonite; BS, blueschist facies; CEc, coesite eclogite facies; EA, epidote amphibolite facies; EBS, epidote blueschist facies; Ec, eclogite facies; GS, greenschist facies; LEc, lawsonite eclogite facies / 
Numbers 1 to 4: see text for details). c) Geological map of the Mt. Emilius klippe (modified after the Chatillon geological map, Dal Piaz et al., 2010) where the location and names of new samples are reported. 


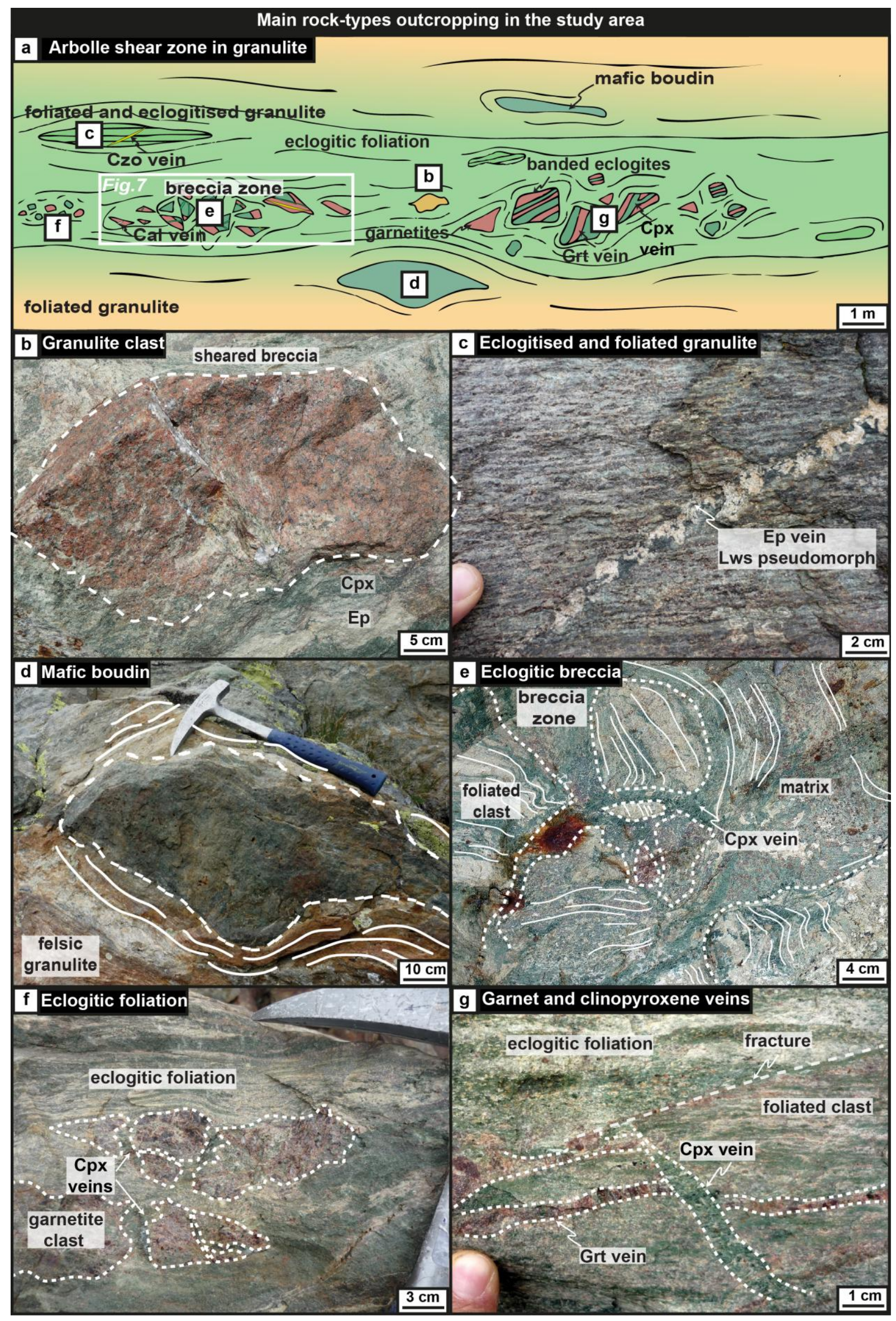


Figure 2: a) Schematic representation of the Arbolle shear zone presenting the different lithologies and their respective locations. b) Granulite clast embedded within the shear zone. c) Eclogitised and foliated granulite crosscut by an epidote vein (lawsonite pseudomorphs). d) Mafic boudin embedded in sheared felsic granulite. e) Eclogitic breccia showing centimetersized, randomly oriented and internally foliated eclogite clasts that are cemented by a matrix comprising clinopyroxene ( $C p x)$, epidote and garnet. f) Boudinaged garnetite clasts embedded in foliation marked by $C p x$, epidote and garnet. g) Internally foliated clast displaying a garnet vein that is in turn crosscut by a $C p x$ vein. The clast is embedded in eclogite with foliation made up by $C p x$, epidote and garnet. All these field photographs have been taken in the Arbolle area above the Echo lake (N4540'6.2"-E007²1'43.8"). (Abbreviations: Cpx, clinopyroxene; Ep, epidote; Grt, garnet; Lws, lawsonite). 


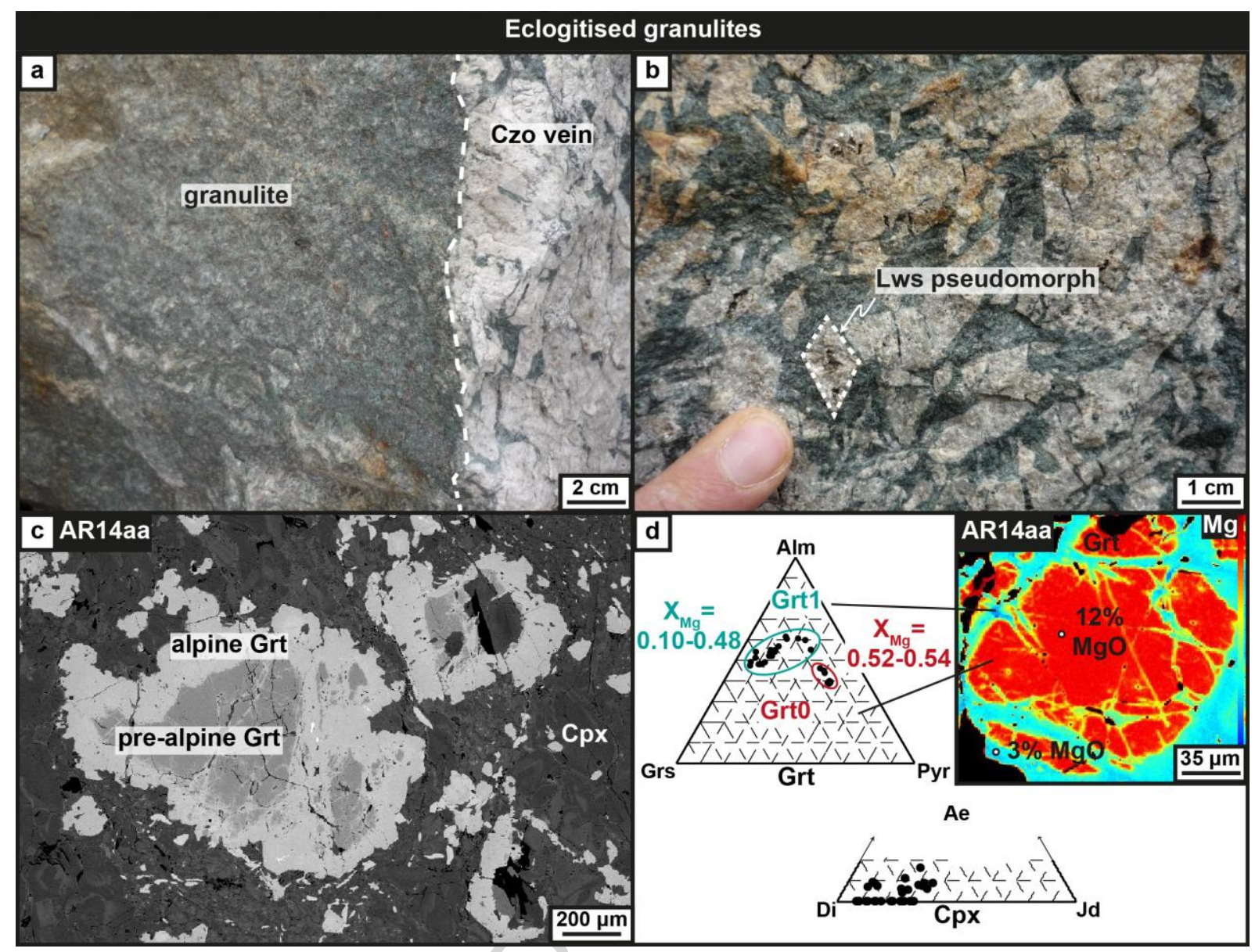

Figure 3: a) Field photograph of eclogitised granulite crosscut by a clinozoisite vein. b) Zoom on the clinozoisite vein from a) showing lozenge shaped lawsonite pseudomorphs in a matrix of calcic amphiboles. c) Back-scattered electron (BSE) image displaying fractured garnet cores (GrtO; dark grey) cemented and rimmed by Grtl (light grey) in a clinopyroxene-rich matrix. d) Top-left inlay on d): compositional ternary diagram showing Grt0 and Grt1 chemical compositions. (Abbreviations: Pyr, pyrope; Alm, almandine; Grs, grossular). Topright inlay on d): X-ray chemical map presenting the $\mathrm{Mg}$ content (mol\%) of high- $\mathrm{Mg}$ fractured GrtO replaced by low-Mg Grt1. Bottom inlay on d): Detail of a compositional ternary diagram showing clinopyroxene compositions. (Abbreviations: Jd, jadeite; Ae, aegyrine; Di, diopside). 


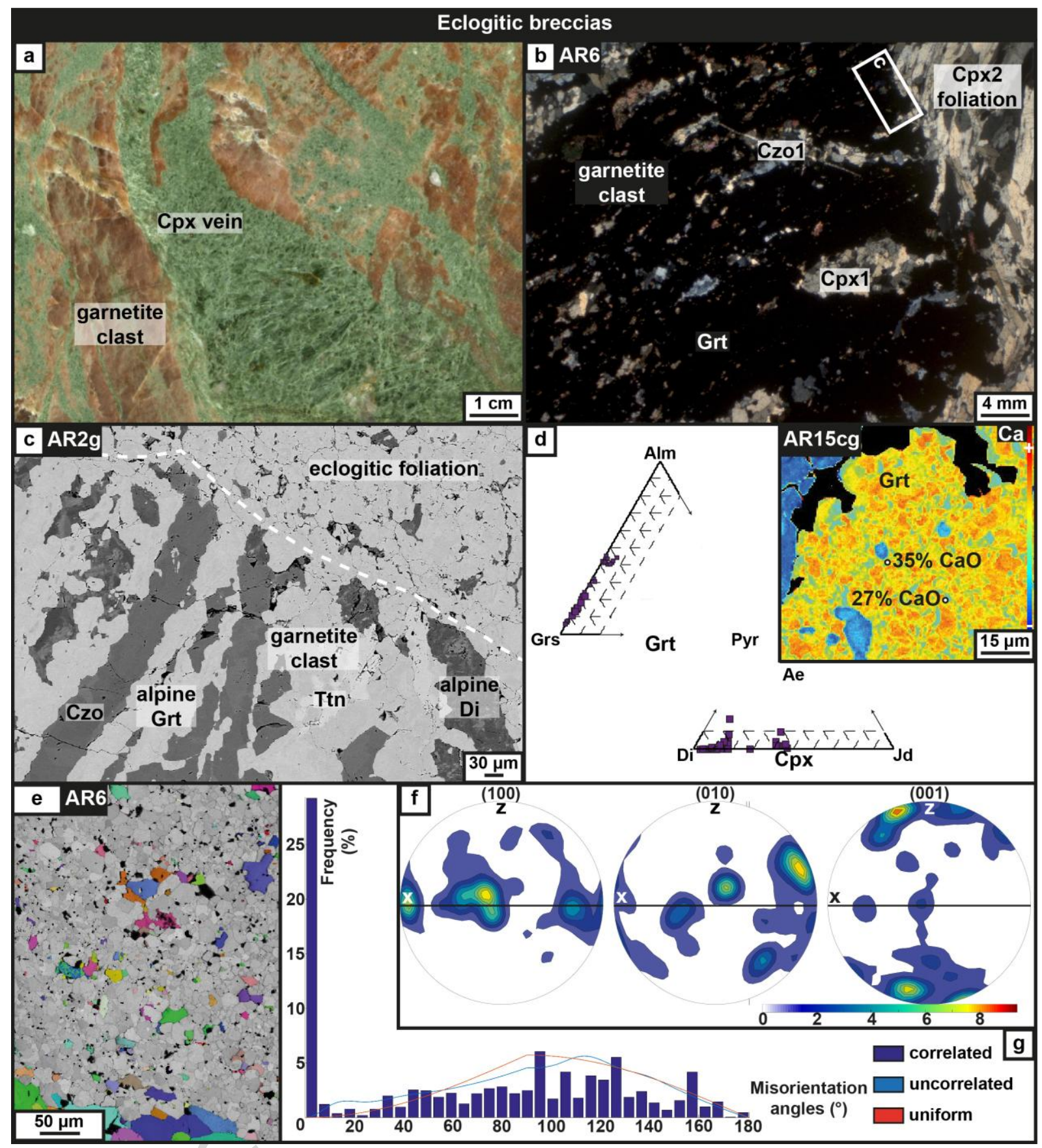

Figure 4: a) Polished rock section showing fractured garnetite clasts cemented by $C p x$. b)

Thin-section photomicrograph under cross- polarised light showing a garnet clast with internal $C p x(C p x 1)$ and clinozoisite $(C z o l)$ foliation, embedded in a second foliation with $C p x(C p x 2)$ and clinozoisite ( $C z o 2)$ foliation sub-perpendicular to the $C p x 1-C z o 1$ foliation. c) BSE image of a garnet clast with an internal $C p x$ and clinozoisite foliation (bottom part), surrounded by an eclogitic foliation (upper right part). d) Garnet and Cpx compositional ternary diagrams, showing, respectively, one group of garnet (Grtl) and two groups of Cpx 
(>80\% Di and $\sim 50 \% \mathrm{Jd}$ ). Top right inlay in d): X-ray chemical map presenting the Ca content variations of a garnet assemblage. (Mineral abbreviations are the same than in Fig. 3d). e) EBSD map presenting $C p x$ interstitial grains (in colour) within a garnetite clast (the grey matrix is made of garnet). Similar colours mean similar crystal orientations. f) Misorientation angle distribution (\% area) performed on the map shown in e). Crystallographic preferred orientations of $C p x$ are plotted in the upper hemisphere of equal-area net. Scale is given in multiples of uniform distribution. $\mathrm{X}, \mathrm{Y}$ and $\mathrm{Z}$ represent the tectonic reference frame. The foliation is vertical and oriented E-W (black line); the lineation is horizontal and oriented EW. ((100) and (001): pole of the plans (100) and (001) respectively; [010], direction of the plan (010)). g) Histogram of misorientation angles displaying the misorientation between two neighbouring Cpx crystals (blue bars), misorientation of uncorrelated boundaries (blue line) and theoretical random distribution (red line). 


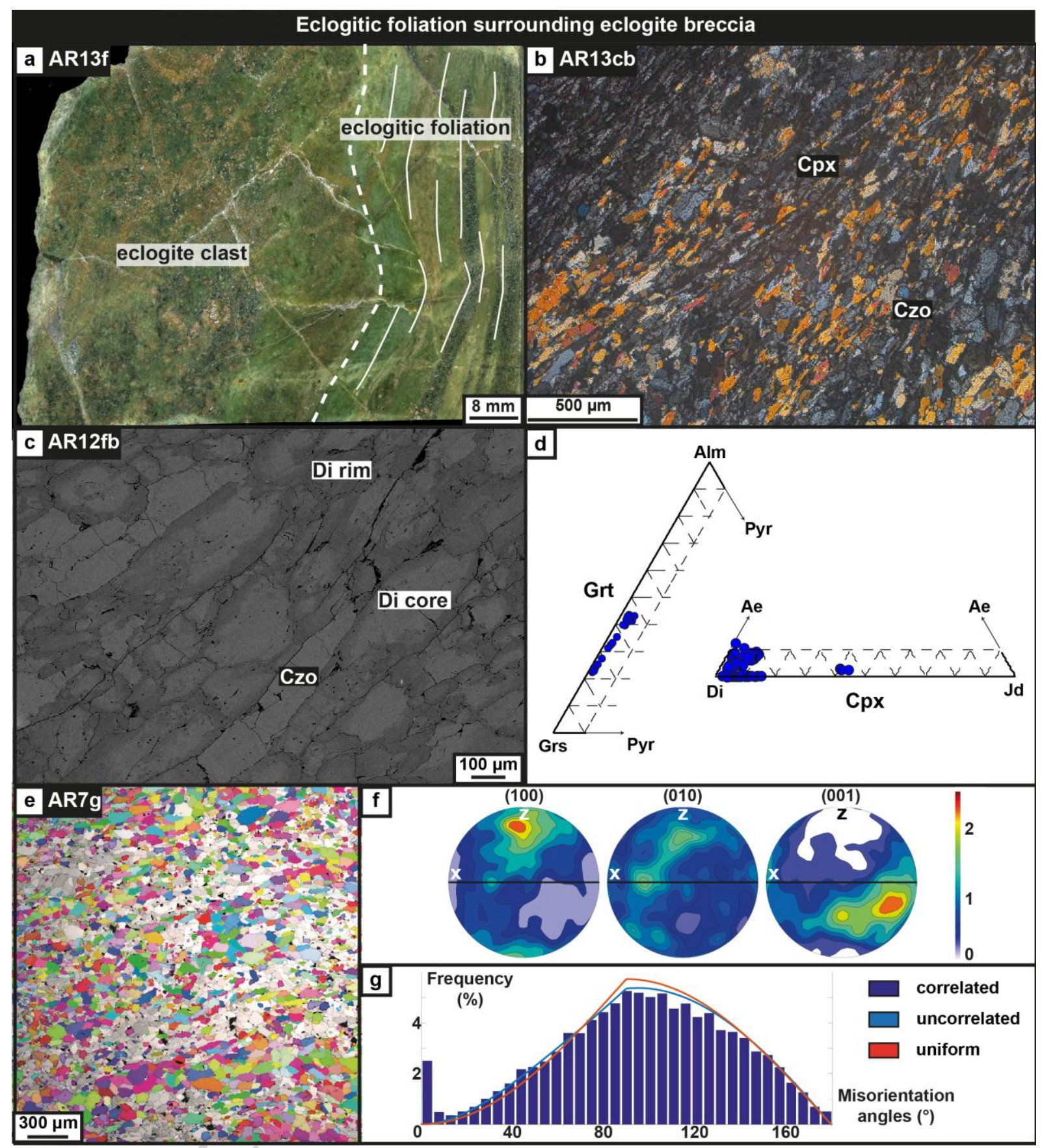

Figure 5: a) Polished rock section showing an eclogite clast embedded in an eclogitic foliation. b) Thin-section photomicrograph under cross-polarised light presenting a Cpx and clinozoisite foliation. c) BSE image displaying a foliation defined by zoned diopside and clinozoisite. d) Details of garnet and Cpx compositional ternary diagrams showing one group of Grtl and two groups of $C p x$ (>80\% Di and $~ 50 \% \mathrm{Jd}$ ), respectively. (Mineral abbreviations are for the same than in Fig. 3d). e) EBSD map presenting the $C p x$ grains (in colour) within the eclogite foliation located around a garnetite clast (other minerals, mainly garnet and 
clinozosoite, appear in grey). Similar colours mean similar crystal orientations. f) Misorientation angle distribution (\% area) performed on the map shown in $e$ ). (Legend is the same than in Fig. 4f). g) Histogram of misorientation angles displaying the misorientation of neighbouring $C p x$ crystals (blue bars), misorientation of uncorrelated boundaries (blue line) and theoretical random distribution (red line). 


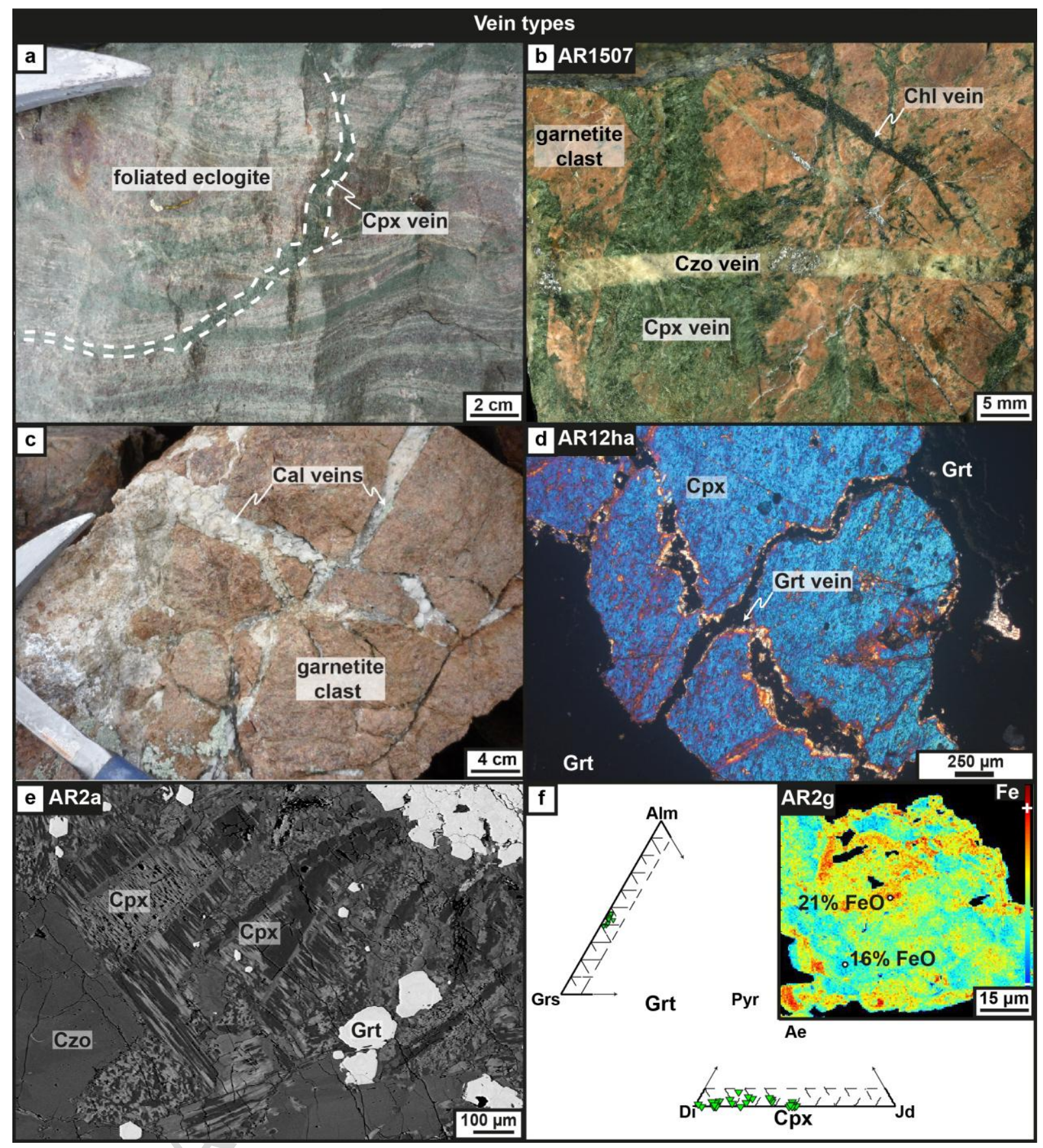

Figure 6: a) Field view of a fracture filled by $C p x$ cutting through an eclogitic foliation with Cpx, clinozoisite and garnet. b) Polished rock section showing garnetite clasts successively crosscut by $C p x$ veins, clinozoisite vein and chlorite vein. c) Field view of calcite veins cutting through a garnetite clast. d) Thins section photomicrograph under cross-polarised light presenting a fractured $C p x$ filled by garnet in a garnet matrix. e) BSE image showing a detail of a $C p x$ vein. f) Details of garnet and $C p x$ compositional ternary diagrams showing 
respectively one group of Grt1 and one group of $C p x$ forming a solid solution between Di and Jd end-members (>80\% Di and $\sim 50 \%$ Jd). Top right inlay on d): X-ray chemical map presenting variations of Fe content (mol\%) in Grtl. (Mineral abbreviations are the same than in Fig. 4d). 


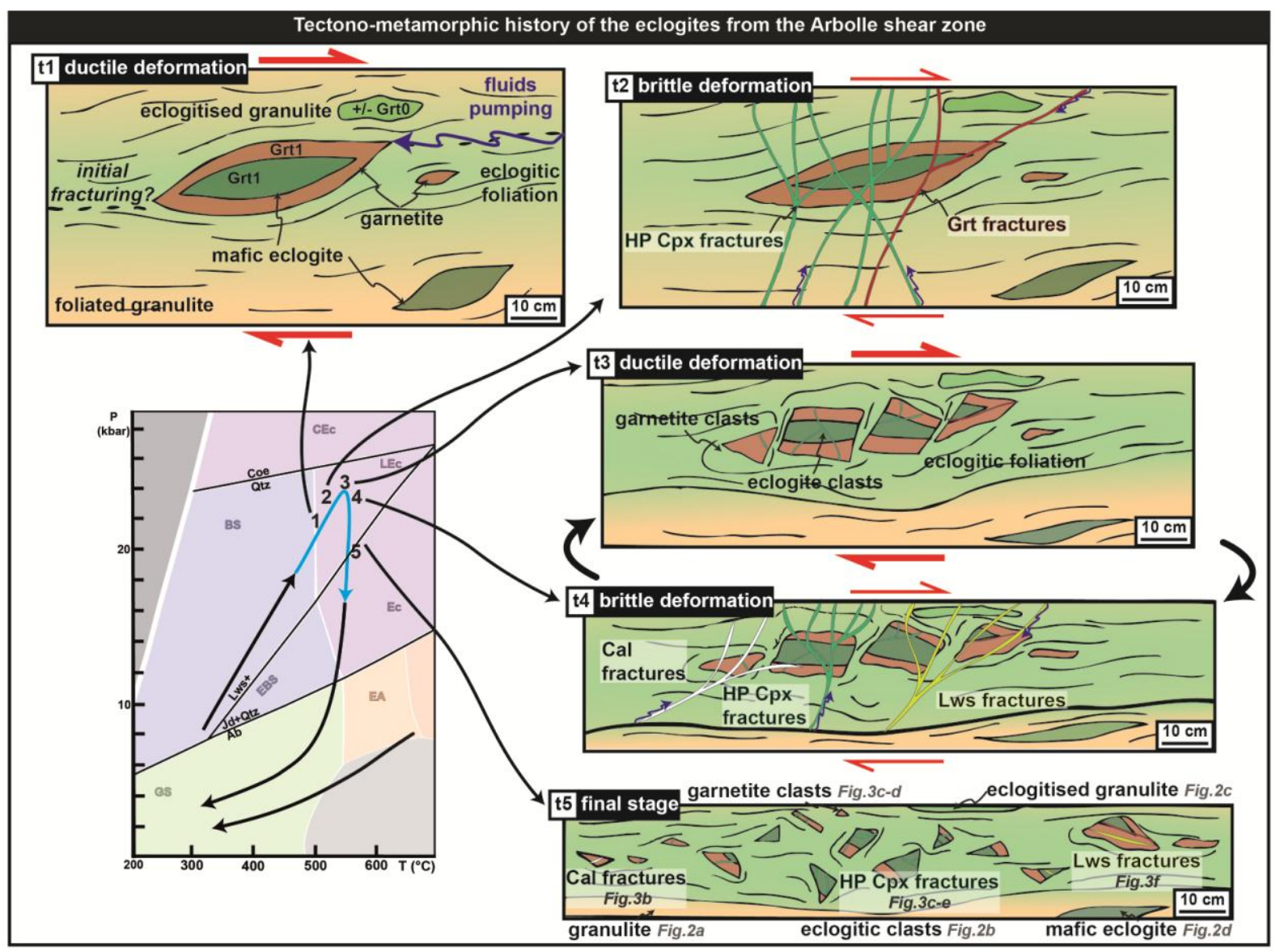

Figure 7: t1) Shear deformation triggered by a first fracturing event and associated with fluid infiltration and metasomatic processes, formation of an eclogitic foliation and garnetite layer around mafic eclogite. t2) Fracturing across the entire shear zone in the eclogite-facies conditions. Fractures are filled by HP CPx and/or garnet and lead to the formation of eclogitic clasts. t3) Eclogitic breccias formation: clasts are embedded in a foliation comprising HP Cpx, clinozoisite and garnet. t4) New fracturing event through the entire shear zone in the eclogitefacies conditions. Fractures are filled by $H P C p x$, lawsonite (statically replaced by clinozoisite and white micas during the retrograde path) and calcite. t5) Present-day structure summarising all the observations presented in this study. Blue arrows correspond to fluid flow into fractures occurring during the brittle events. 
Table

\begin{tabular}{|c|c|c|c|c|c|c|c|c|c|c|c|c|c|}
\hline \multirow{3}{*}{$\begin{array}{l}\text { mineral } \\
\text { location } \\
\text { sample }\end{array}$} & \multicolumn{5}{|c|}{ Garnet } & \multicolumn{6}{|c|}{ HP Clinopyroxene } & \multicolumn{2}{|c|}{ Clinozoisite } \\
\hline & \multirow{2}{*}{\multicolumn{2}{|c|}{$\begin{array}{l}\text { granulite } \\
\text { AR1414aa }\end{array}$}} & \multirow{3}{*}{$\begin{array}{c}\text { clast } \\
\text { AR15cg } \\
38.49\end{array}$} & \multirow{3}{*}{$\begin{array}{l}\text { foliation } \\
\text { AR2g } \\
38.30\end{array}$} & \multirow{3}{*}{$\begin{array}{c}\text { vein } \\
\text { AR7g } \\
39.30\end{array}$} & \multirow{2}{*}{\multicolumn{2}{|c|}{$\begin{array}{l}\text { granulite } \\
\text { AR1414aa }\end{array}$}} & \multicolumn{2}{|c|}{ clast } & \multirow{2}{*}{$\begin{array}{c}\text { foliation } \\
\text { AR6 }\end{array}$} & \multirow{2}{*}{$\begin{array}{l}\text { vein } \\
\text { AR2a }\end{array}$} & \multirow{2}{*}{$\begin{array}{l}\text { granulite } \\
\text { AR1414aa }\end{array}$} & \multirow{2}{*}{$\begin{array}{c}\text { foliation } \\
\text { AR6 }\end{array}$} \\
\hline & & & & & & & & AR2g & AR6 & & & & \\
\hline \%SiO2 & 40.07 & 38.46 & & & & 55.48 & 53.71 & 55.62 & 54.19 & 54.80 & 55.66 & 40.08 & 39.61 \\
\hline$\%$ TiO2 & 0.07 & 0.12 & 0.09 & 0.25 & 0.15 & 0.04 & 0.01 & 0.00 & 0.00 & 0.00 & 0.00 & 0.33 & 0.12 \\
\hline$\% A I 2 O 3$ & 22.22 & 21.21 & 20.58 & 21.28 & 20.29 & 3.30 & 2.91 & 10.51 & 0.97 & 2.18 & 8.41 & 29.08 & 28.07 \\
\hline$\% F e O$ & 19.09 & 23.44 & 8.78 & 17.87 & 11.00 & 7.10 & 8.29 & 6.99 & 5.36 & 4.62 & 5.35 & 5.25 & 6.94 \\
\hline$\% \mathrm{MnO}$ & 0.65 & 1.08 & 1.13 & 1.52 & 1.64 & 0.06 & 0.04 & 0.00 & 0.00 & 0.00 & 0.00 & 0.13 & 0.05 \\
\hline \%MgO & 11.74 & 3.48 & 0.25 & 1.00 & 0.23 & 19.78 & 12.14 & 5.89 & 14.94 & 14.52 & 8.70 & 0.04 & 0.06 \\
\hline$\% \mathrm{CaO}$ & 5.89 & 11.86 & 30.62 & 18.05 & 26.18 & 12.55 & 20.50 & 13.19 & 22.87 & 21.65 & 15.41 & 23.74 & 23.33 \\
\hline$\% \mathrm{Na2O}$ & 0.00 & 0.02 & 0.05 & 0.00 & 0.00 & 1.28 & 2.37 & 6.93 & 1.07 & 1.71 & 5.88 & 0.00 & 0.02 \\
\hline \%K2O & 0.00 & 0.00 & 0.00 & 0.00 & 0.00 & 0.00 & 0.00 & 0.00 & 0.00 & 0.00 & 0.00 & 0.02 & 0.00 \\
\hline sum & 99.73 & 99.67 & 99.98 & 98.27 & 98.79 & 99.59 & 99.97 & 99.13 & 99.40 & 99.48 & 99.41 & 98.67 & 98.21 \\
\hline oxygens & 12 & 12 & 12 & 12 & 12 & 4 & 4 & 1 & $T$ & 4 & 4 & 12 & 12 \\
\hline Si & 3.01 & 3.02 & 2.95 & 3.04 & 3.07 & 2.00 & 1.98 & 2.02 & 2.03 & 2.07 & 2.01 & 3.08 & 3.04 \\
\hline $\mathrm{Ti}$ & 0.00 & 0.01 & 0.01 & 0.01 & 0.01 & 0.00 & 0.00 & 0.00 & 0.00 & 0.00 & 0.00 & 0.02 & 0.01 \\
\hline Al & 1.96 & 1.96 & 1.86 & 1.99 & 1.87 & 0.14 & 0.13 & 0.45 & 0.04 & 0.10 & 0.36 & 2.63 & 2.54 \\
\hline $\mathrm{Fe}$ & 1.20 & 1.54 & 0.56 & 1.19 & 0.72 & 0.21 & 0.25 & 0.21 & 0.17 & 0.15 & 0.16 & 0.34 & 0.45 \\
\hline Mn & 0.04 & 0.07 & 0.07 & 0.10 & 0.11 & 0.00 & 0.00 & 0.00 & 0.00 & 0.00 & 0.00 & 0.01 & 0.00 \\
\hline Mg & 1.31 & 0.41 & 0.03 & 0.12 & 0.03 & 1.06 & 0.67 & 0.32 & 0.84 & 0.82 & 0.47 & 0.00 & 0.01 \\
\hline $\mathrm{Ca}$ & 0.47 & 1.00 & 2.51 & 1.54 & 2.19 & 0.49 & 0.81 & 0.51 & 0.92 & 0.87 & 0.60 & 1.95 & 1.92 \\
\hline $\mathrm{Na}$ & 0.00 & 0.00 & 0.01 & 0.00 & 0.00 & 0.09 & 0.17 & 0.49 & 0.00 & 0.00 & 0.41 & 0.00 & 0.00 \\
\hline $\mathrm{K}$ & 0.00 & 0.00 & 0.00 & 0.00 & 0.00 & 0.00 & 0.00 & 0.00 & 0.00 & 0.00 & 0.00 & 0.00 & 0.00 \\
\hline
\end{tabular}

Table 1: Representative analyses of garnet, $H P$ clinopyroxene and clinozoisite from granulites, clasts, foliations and veins (Mt. Emilius klippe). 


\section{Highlight}

We present a structural and petro-chemical analysis of eclogites from the Mt. Emilius

We show that both brittle and ductile behaviour alternate during HP deformation

Brittle deformation events occur close to the peak of metamorphism $\left(\sim 2.3 \mathrm{GPa} / 525^{\circ} \mathrm{C}\right)$

HP fracturing events lead to breccias and veins associated to fluid circulation

We discuss the causes and consequences of such switches on subduction dynamics 